\title{
PENGEMBANGAN MEDIA PEMBELAJARAN PAI BERBASIS AUGMENTED REALITY
}

\author{
Lukman Hakim \\ Universitas Nurul Jadid (UNUJA) \\ Karanganyar, Paiton, Probolinggo, Jawa Timur, Indonesia \\ Email: lukman.aquariusxx@gmail.com
}

\begin{abstract}
Abstrak:
Pembelajaran dapat berjalan efektif jika seluruh komponen yang berpengaruh saling mendukung untuk mencapai tujuan pembelajaran. Untuk memperlancar kegiatan belajar mengajar, terutama dalam Pembelajaran Agama Islam (PAI) guru hendaknya mempersiapkan bahan ajar untuk membantu memudahkan peserta didik memahami materi pembelajaran. Oleh sebab itu, diperlukan suatu media pembelajaran yang tepat, salah satunya adalah media berbasis Augmented Reality (3D). Augmented Reality (3D) merupakan aplikasi penggabungan dunia nyata dengan dunia maya dalam bentuk dua dimensi maupun tiga dimensi yang diproyeksikan dalam sebuah lingkungan nyata dalam waktu yang bersamaan. Tujuan penggunaan teknologi Augmented Reality dalam model pembelajaran PAI diharapkan dapat membantu guru dalam proses pembelajaran dan juga mampu meningkatkan minat peserta didik dalam mengikuti proses pembelajaran. Metode yang digunakan dalam penelitian ini adalah metode penelitian dan pengembangan (Research and Development) yang dirancang oleh Walter Dick dan Lou Carey yang mana akan menghasilkan produk tertentu. Hasil dari penelitian adalah sebuah aplikasi Augmented Reality yang dapat berjalan di dalam smartphone android.
\end{abstract}

\begin{abstract}
:
Learning can work effectively if all the influential components support each other to achieve the learning objectives. To facilitate teaching and learning activities, especially in learning Islamic Religious Learning (PAI) teachers should prepare teaching materials to facilitate students understand learning materials. Therefore, it is necessary to develop an appropriate learning media. One of them is Augmented Reality (3D) based media. Augmented Reality (3D) is a real-world application of integration with the virtual world in the form of two-dimensional and three-dimensional projected in a real environment at the same time. The purpose of using Augmented Reality technology in PAI learning model is expected to assist the teacher in the learning process and also increase the students' interest in joining the learning process. The method used in this study is the research and development method designed by Walter Dick and Lou Carey to produce a particular product. The result of the research is an Augmented Reality application that can run inside android smartphone.
\end{abstract}




\section{Kata kunci : \\ Pengembangan Media Pembelajaran, Augmented Reality (3d)}

PERKEMBANGAN teknologi dan ilmu pengetahuan yang semakin pesat berpengaruh terhadap proses pembelajaran di sekolah dan berpengaruh juga pada materi pembelajaran serta cara penyampaian materi dalam proses belajar mengajar. (Dengeng, 2001) menyatakan bahwa pembelajaran merupakan suatu upaya dalam membelajarkan pelajar (peserta didik). Pengertian lain tentang pembelajaran adalah upaya yang dilakukan oleh tenaga pengajar (guru, instruktur) yang bertujuan untuk membantu peserta didik agar mampu belajar dengan mudah. Usaha ini dijalankan dalam sebuah proses yang sistematis yang dijalankan dalam sebuah sistem dan setiap komponen dalam sistem itu memiliki arti untuk keberhasilan belajar peserta didik. Dalam proses tersebut, komunikasi merupakan unsur yang mutlak diperlukan. Dalam hal ini, proses pembelajaran yang sesungguhnya adalah suatu proses komunikasi. Adapun komponen penting yang menentukan efektivitas proses pembelajaran adalah guru, peserta didik, materi, metode, media dan situasi (Asyhar, 2012) Menurut UU Sisdiknas No 20 Tahun 2003:

"Pembelajaran adalah proses interaksi peserta didik dengan pendidik dan sumber belajar pada suatu lingkungan belajar. Pembelajaran sebagai proses belajar yang dibangun oleh guru untuk mengembangkan kreatifitas berfikir yang dapat meningkatkan kemampuan berfikir peserta didik serta dapat meningkatkan kemampuan mengkontruksi pengetahuan baru sebagai upaya meningkatkan penguasaan yang baik terhadap materi pembelajaran."

Pembelajaran adalah kegiatan guru secara terprogram dalam desain instruksional, untuk membuat peserta didik belajar secara aktif yang menekankan pada penyediaan sumber belajar (Mudjiono, 2013). pembelajaran merupakan suatu proses belajar yang berulang-ulang dan menyebabkan adanya perubahan perilaku yang disadari dan cenderung bersifat tetap. Pembelajaran memiliki makna bahwa subjek belajar harus dibelajarkan bukan diajarkan. Subjek belajar yang dimaksud adalah peserta didik yang menjadi pusat kegiatan belajar. Peserta didik sebagai subjek belajar dituntut untuk aktif mencari, menemukan, menganalisis, merumuskan masalah, dan menyimpulkan suatu masalah.

Berdasarkan hal tersebut, maka pembelajaran adalah suatu proses kegiatan yang berupaya untuk mengelola terjadinya proses belajar yang efektif dengan tujuan untuk memaksimalkan proses belajar peserta didik. Dapat disimpulkan bahwa pembelajaran merupakan proses interaksi antara guru dengan peserta didik yang ditujukan untuk melakukan perubahan sikap dan pola pikir peserta didik kearah yang lebih baik untuk mencapai hasil belajar yang optimal.

Pendidikan Agama Islam (PAI) menurut Muhaimin (2004) adalah suatu upaya untuk membuat peserta didik dapat belajar, butuh belajar, terdorong belajar, mau belajar dan tertarik untuk terus-menerus mempelajari agama Islam, baik untuk 
mengetahui bagaimana cara beragama yang benar maupun mempelajari Islam sebagai pengetahuan.

Menurut Zakiyah Darajdat yang dikutip oleh Abdul Majid dan Dian Andayani (Andayani, 2004), "Pendidikan agama Islam adalah suatu usaha untuk membina dan mengasuh peserta didik agar senantiasa dapat memahami ajaran Islam secara menyeluruh, lalu menghayati tujuan, yang pada akhirnya dapat mengamalkan serta menjadikan Islam sebagai pandangan hidup.

Dengan demikian pembelajaran PAI dapat diartikan sebagai upaya membuat peserta didik dapat belajar, terdorong belajar, mau belajar dan tertarik untuk terus menerus mempelajari apa yang teraktualisasikan dalam kurikulum agama Islam sebagai kebutuhan peserta didik secara menyeluruh yang mengakibatkan beberapa perubahan yang relatif tetap dalam tingkah laku seseorang baik dalam kognitif, efektif dan psikomotorik.

Pemaknaan pembelajaran pendidikan agama Islam merupakan bimbingan menjadi muslim yang tangguh dan mampu merealisasikan ajaran Pendidikan Agama Islam dalam kehidupan sehari-hari sehingga menjadi insan kamil. Untuk itu penanaman Pembelajaran PAI sangat penting dalam membentuk dan mendasari peserta didik. Dengan penanaman pembelajaran PAI sejak dini diharapkan mampu membentuk pribadi yang kokoh, kuat dan mandiri untuk berpedoman pada agama Islam.

Media pembelajaran sangat diperlukan oleh guru untuk membantu menyampaikan materi dalam sebuah proses pembelajaran. Peserta didik cenderung lebih tertarik dan mudah memahami apabila proses pembelajarannya menggunakan sebuah animasi serta peserta didik akan lebih mudah dalam mengingatnya dan dapat memaksimalkan hasil belajar yang dicapai.

Peran para guru sebagai sumber belajar merupakan peran yang sangat penting, karena peran sebagai sumber belajar berkaitan erat dengan penguasaan materi pelajaran. Maka kita bisa menilai baik atau tidaknya seorang guru berdasarkan bagaimana ia dapat menguasai materi pelajaran dengan baik, sehingga benar-benar hal tersebut berperan sebagai sumber belajar bagi anak didiknya, dan apabila seorang guru yang kurang baik manakala ia tidak paham tentang materi yang diajarkannya sehingga peserta didik akan merasa jenuh dan kurang memperhatikannya maka dalam hal ini proses belajar mengajar akan terhambat sehingga peserta didik kurang memahami tentang materi yang telah di sampaikan oleh gurunya. Oleh karena itu, diperlukan media pembelajaran untuk mendukung proses pembelajaran.

Menurut Gagne \& Briggs dalam (Arsyad, 2009) mengatakan bahwa media pembelajaran meliputi alat yang secara fisik digunakan untuk menyampaikan isi materi pengajaran, yang terdiri dari antara lain buku, tape recorder, kaset, video kamera, video recorder, film, slide (gambar bingkai), foto, gambar, grafik, televisi, dan komputer. Dengan kata lain, media adalah komponen sumber belajar atau wahana fisik yang mengandung materi instruksional di lingkungan peserta didik untuk belajar. 
Media menjadi faktor yang penting dalam kegiatan pembelajaran. Melaui media guru dapat terbantu dalam menyampaikan materi. Kegiatan pembelajaran menjadi lebih hidup dengan adanya media. Peserta didik turut merasakan manfaat dengan adanya media yang digunakan, namun sebuah media belum tentu dapat menjangkau seluruh kalangan peserta didik. Keterbatasan trainer atau modul yang digunakan sebagai media pembelajaran menjadi salah satu penghambatnya. Hal lain yang juga menjadi penghambat adalah karekteristik dan kemampuan peserta didik yang berbeda-beda dalam menyerap materi yang disampaikan.

Kesesuaian media dengan peserta didik menjadi dasar pertimbangan utama, sebab hampir tidak ada satu media yang dapat memenuhi semua tingkatan usia. Perlu perancangan yang matang sehingga media dapat tepat sasaran dalam penggunaannya (Riyana, 2009).

Media pembelajaran merupakan salah satu komponen dalam lingkungan pembelajaran yang dapat merangsang peserta didik untuk belajar. Media pembelajaaran dapat dijadikan stimulus untuk meningkatkan kemauan peserta didik sehingga mengikuti proses belajar mengajar dengan baik (Baharun, 2016).

Penggunaan media pembelajaran dalam mengajarkan materi Pendidikan Agama Islam bukanlah sekedar upaya untuk membantu guru, namun juga membantu peserta didik dalam belajar. Penggunaan media akan membantu peserta didik untuk lebih fokus pada apa yang disampaikan oleh guru, dapat meningkatkan pemahaman peserta didik, serta dapat menerima pesan dengan baik dan benar. Media pembelajaran juga dapat membantu agar tidak adanya kesimpangsiuran antara pesan yang ingin disampaikan oleh guru dengan pesan yang diterima oleh peserta didik.

Oleh karena itu, penggunaan media sangat dianjurkan dalam mengembangkan pembelajaran, khususnya pembelajaran Pendidikan Agama Islam. Beberapa hal harus diperhatikah oleh seorang guru dalam menentukan media pembelajaran.

Salah satu media pembelajaran yang diharapkan bisa membuat peserta didik lebih memahami materi yang didapatkan salah satunya dengan menggunakan teknologi Augmented Reality. Teknologi ini mungkin bagi sebagian orang masih terdengar asing. Pada umunya teknologi ini aplikasinya dikembangkan di PC dekstop, namun seiring kemajuan teknologi banyak aplikasi yang mengadopsi teknologi Augmented Reality kedalam sebuah aplikasi smartphone.

Pada tahun 1997, Azuma menggagaskan adanya penggabungan antara suatu objek nyata dengan objek virtual yang memiliki bentuk 3 Dimensi (3D) dengan lingkungan luar yang nyata secara real-time yang saat ini dikenal dengan sebutan Augmented Reality (AR). AR merupakan pengembangan dari Virtual Reality atau yang pernah disebut sebagai Virtual Environtment (VE). Teknologi VE akan membawa user ke dalam lingkungan sintetis yang dirancang meyerupai lingkungan sebenarnya, namun AR akan lebih membawa user untuk dapat membayangkan gambaran objek secara detil dalam bentuk 3 dimensi pada dunia nyata (Ardhianto, 2012). 
Augmented Reality merupakan penggabungan benda-benda nyata dan maya di lingkungan nyata, berjalan secara interaktif dalam waktu nyata, dan terdapat integrasi antar benda dalam tiga dimensi, yaitu benda maya terintegrasi dalam dunia nyata (Ronald, 1997).

Augmented reality (AR) adalah sebuah tampilan real-time langsung atau tidak langsung dari sebuah fisik sebuah objek nyata dengan menambahkan objek pada dunia maya sehingga menghasilkan informasi tambahan pada objek yang ada. Augmented reality ini menggabungkan benda-benda nyata dan virtual objek yang ada, virtual objek ini hanya bersifat menambahkan bukan menggantikan objek nyata, sedangkan tujuan dari augmented reality ini adalah menyederhanakan objek nyata dengan membawa objek maya sehingga informasi tidak hanya untuk pengguna secara langsung (user interface), tetapi juga untuk setiap pengguna yang tidak langsung berhubungan dengan user interface dari objek nyata, seperti live-streaming video. Perangkat utama untuk augmented reality adalah display, perangkat input, tracking, dan komputer (Djamarah, 2006)

$A R$ Interface Salah satu aspek paling penting dari augmented reality yang berfungsi untuk menciptakan sesuai teknik interaksi intuitif antara pengguna dan konten virtual AR aplikasi. Ada empat cara utama interaksi dalam aplikasi AR: tangible $A R$ interface, kolaboratif $A R$ interface, hibrida $A R$ interface, dan muncul multimodal interface.

a. Tangible Interface

Berwujud interface yang mendukung interaksi secara langsung dengan dunia nyata dengan memanfaatkan objek nyata, salah satu contoh dari tangible interface ini adalah pada aplikasai virtual fittng room dan game augmented reality pringleys dimana tabung dari kemasan pringleys menjadi marker dan kontrol dari game tersebut.

b. Kolaborasi AR Interface

Kolaborasi AR interface menampilkan beberapa tampilan untuk mendukung suatu kegiatan dalam berbagi interface 3D untuk meningkatkan interaksi kolaboatif dengan banyak perangkat dan banyak user. Interface ini dapat diintegrasikan dengan aplikasi medis untuk melakukan diagnosa operasi.

c. Interface Hybrid

menggabungkan berbagai macam device berbeda, tetapi saling melengkapi interface serta memungkinan untuk berinteraksi melalui berbagai perangkat interaksi, contoh pada aplikasi Augmented Reality yang menggunakan sarung tangan dan kacamata (Jogiyanto, 1990).

Animasi 3D adalah animasi yang berwujud 3 dimensi. Meskipun bukan dalam wujud 3D yang sebenarya, yaitu bukan sebuah objek 3D yang dapat anda sentuh dan rasakan wujud fisiknya, namun dalam wujud 3D dalam layar kaca 2D (media layar $\mathrm{TV}$, bioskop, computer dan media sejenisnya). Tidak seperti animasi 2D yang hanya memiliki dimensi panjang $(X)$ dan lebar $(Y)$, animasi 3D selain memiliki kedua dimensi tersebut juga memiliki dimensi kedalaman (Z). Animasi 2D bersifat datar 
(flat), sedangkan animasi 3D memiliki kedalaman (volume) bentuk. Animasi 3D dapat didefinisikan sebagai animasi yang dapat dilihat dari berbagai sudut pandang (Aditya, 2009).

Pada dasarnya, prinsip kerja Augmented Reality adalah pelacakan (tracking) dan dan rekonstruksi (reconstruction). Pada mulanya marker dideteksi menggunakan kamera. Cara deteksi dapat melibatkan berbagai macam algoritma misal edge detection, atau algoritma image processing lainnya. Data yang diperolehdari proses pelacakan digunakan dalam rekonstruksi sistem koordinat di dunia nyata. Disamping menambahkan obyek kedalam lingkungan nyata, Augmented Reality juga dapat menghilangkan obyek nyata dalambentuk virtual. Dengan menutupi obyek nyata tersebut dengan disain grafis sesuai lingkungannya, maka obyek nyata akan tersembunyi dari pengguna.

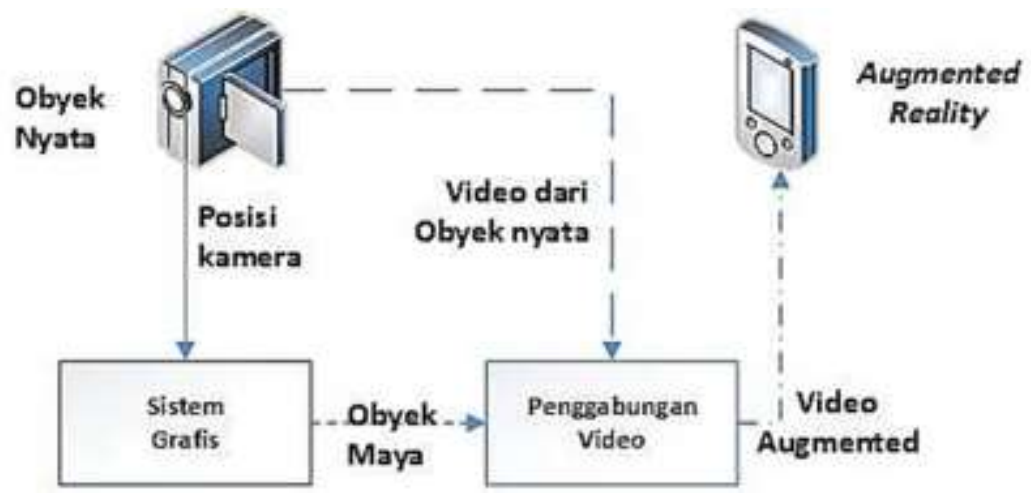

Gambar 1. Diagram Kerja Augmented Reality

Pada gambar 1 terlihat bagaimana Augmented Reality bekerja. Menurut penelitian (Ronald, 1997) menyebutkan bahwa sebuah Augmented Reality sedikitnya memiliki tiga karakteristik: 1) kombinasi nyata dengan maya, 2) interaktif dan dalam waktu nyata, 3) disajikan dalam bentuk tiga Dimensi. Obyek nyata beserta marker yang sudah dipasangakan dideteksi oleh kamera, kemudian informasi dari kamera diteruskan ke sistem grafis berupa posisi kamera, yang berisi data grafis obyek virtual. Informasi berupa video obyek nyata diteruskan ke penggabungan video. Dalam sistem grafis, posisi kamera menentukan sudut pandang obyek maya yang akan ditampilkan. Dalam penggabungan video, informasi dari sistem grafis digabung dengan video nyata dari kamera. Hasil penggabungan akan ditampilkan pada layar smartphone yang sudah berupa Augmented Reality. (Mustaqim, Ilmawan \& Kurniawan, 2017)

\section{METODE PENELITIAN}

Metode penelitian yang digunakan pada penelitian ini adalah metode penelitian dan pengembangan (Research and Development) yaitu dengan 
mengembangkan suatu produk dan menguji kefektifan produk tersebut. Metode penelitian dan pengembangan (Research and Development) adalah metode penelitian yang digunakan untuk menghasilkan produk tertentu, dan menguji keefektifan produk tersebut (Sugiyono, 2013). Penelitian pengembangan bersifat analisis kebutuhan dan dapat menguji keefektifan produk yang dihasilkan supaya dapat berfungsi di masyarakat luas.

Model penelitian dan pengembangan pendidikan (Educational Research and Development) yang dapat digunakan adalah model pendekatan sistem yang dirancang oleh Walter Dick dan Lou Carey(Dick, 2015). Model Dick \& Carey dimodifikasi oleh Atwi (Suparman, 2012) dalam buku desain instruksional modern menjadi model pengembangan instruksional (MPI). (Putri, Bakri, \& Permana, 2016)

Langkah-langkah pelaksanaan penelitian dan pengembangan MPI menurut (Suparman, 2012), yaitu:

a. Mengidentifikasi Kebutuhan Instruksional dan Menulis Tujuan Instruksional Umum (TIU)

Pada tahap ini peneliti melakukan analisis kebutuhan instruksional dengan melakukan studi literatur daripenelitian-penelitian yang ada untuk mengetahui kesenjangan antara media pembelajaran yang sudah dikembangkan dengan media pembelajaran yang dibutuhkan oleh peserta didik dan guru pada masa sekarang.

b. Melakukan Analisis Instruksional

Analisis instruksional adalah proses menjabarkan kompetensi umum menjadi sub kompetensi, kompetensi dasar atau kompetensi khusus yang tersusun secara logis dan sistematik.

c. Mengidentifikasi Perilaku dan Karakteristik Awal Peserta Didik

Pada langkah dilakukan analisis terhadap pembelajar, analisis konteks di mana mereka akan belajar, dan analisis konteks di mana mereka akan menggunakannya. Keterampilan pembelajar, pilihan, dan sikap yang telah dimiliki pembelajar akan digunakan untuk merancang strategi instruksional.

d. Menulis Tujuan Instruksional Khusus (TIK)

Tujuan instruksional khusus berasal dari keterampilan yang diidentifikasi dalam analisis Instruksional, akan mengidentifikasi keterampilan yang harus dipelajari, kondisi di mana keterampilan yang harus dilakukan, dan kriteria untuk kinerja yang sukses.

e. Menyusun Alat Penilaian Hasil Belajar

Berdasarkan tujuan yang telah ditulis, langkah ini adalah mengembangkan butirbutir penilaian yang sejajar (tes acuan patokan) untuk mengukur kemampuan peserta didik seperti yang diperkirakan dari tujuan. Penekanan utama berkaitan diletakkan pada jenis keterampilan yang digambarkan dalam tujuan dan penilaian yang diminta.

f. Menyusun Strategi Instruksional 
Bagian-bagian siasat instruksional menekankan komponen untuk mengembangkan pembelajar termasuk kegiatan pra-instruksional, presentasi isi, partisipasi peserta didik, penilaian, dan tindak lanjut kegiatan.

g. Mengembangkan Bahan Instruksional

Ketika kita menggunakan istilah bahan instruksional sudah termasuk segala bentuk instruksional seperti panduan guru, modul, overhead transparansi, kaset video, komputer berbasis multimedia, dan halaman web untuk instruksional jarak jauh.

h. Menyusun Desain dan Melaksanakan Evaluasi Formatif

Pada evaluasi formatif dilakukan uji lapangan skala kecil yaitu melakukan uji keterbacaan. Setiap jenis penilaian memberikan informasi yang berbeda bagi perancang untuk digunakan dalam meningkatkan Instruksional.

i. Sistem Instruksional

Strategi Instruksional ditinjau kembali dan akhirnya semua pertimbangan ini dimasukkan ke dalam revisi instruksional untuk membuatnya menjadi media instruksional lebih efektif.

j. Implementasi, Evaluasi Sumartif dan Difusi Inovasi

Hasil-hasil pada tahap di atas dijadikan dasar untuk membuat media yang dibutuhkan. Media tersebut selanjutnya divalidasi dan diujicobakan di kelas atau diimplementasikan di kelas dengan evaluasi sumatif (Putri, Bakri, \& Permana, 2016).

\section{Pembuatan Aplikasi Media Pembelajaran}

Sebelum membuat aplikasi media pembelajaran, ada tahapan yang harus dilakukan, untuk menghasilkan media yang dapat menutupi kekurangan trainer atau modul praktikum yang digunakan sekaligus dapat menjangkau seluruh peserta didik. Tahapan yang perlu diperhatikan dalam membuat aplikasi media pembelajaran adalah: 1) menentukan konsep dan bentuk media pembelajaran, 2) menentukan kompetensi dasar yang akan dicapai peserta didik, 3) menentukan materi yang akan dimuat dalam media pembelajaran, 4) Menentukan evaluasi yang digunakan untuk mengetahui sejauh mana keberhasilan media pembelajaran yang digunakan.

Dalam membuat aplikasi media pembelajaran Menurut (Legya, 2015) dalam ada tahapan-tahapan yang harus dilalui. Diman hal ini harus dilakukan agar aplikasi media pembelajaran yang akan kita dibuat bekerja secara optimal sesuai dengan target perencanaan. Adapun tahapan yang harus dilakukan adalah:

a. Tahap Pengumpulan Spesifikasi Kebutuhan Pengguna

1. Analisis Kebutuhan

Pada tahap ini, dilakukan identifikasi kebutuhan apa saja yang diperlukan dalam perancangan media pembelajaran. Guru perlu melakukan observasi secara menyeluruh terhadap mata pelajaran yang akan diajarkan kepada peserta didik, kompetensi dasar yang ingin dicapai dalam pembelajaran, 
kemampuan peserta didik dalam menggunakan aplikasi, dan kemanfaatan aplikasi sebagai penunjang kegiatan praktikum atau ujian.

2. Analisis Perangkat Keras

Tahap analisis perangkat keras, maksudnya adalah melakukan identifikasi spesifikasi perangkat keras yang akan digunakan untuk membangun aplikasi media pembelajaran, dan menjalakan aplikasi media pembelajaran sebagai uji coba awal. Analisis perangkat keras meliputi spesifikasi perangkat keras komputer, dan spesifikasi smartphone.

3. Analisis Perangkat Lunak

Perangkat lunak sebagai penunjang dalam pembangunan media pembelajaran perlu diidentifikasi. Dalam mengembangkan multimedia Augmented Reality akan dikenalkan dengan beberapa software yang biasa digunakan untuk membuat aplikasi Augmented Reality, seperti Unity3D, ARToolKit, FLARToolKit, Junaio, IN2AR, D'Fusion Studio, OpenSpace3D, dan Qualcomm. Software-software tersebut ada yang diperuntukan untuk komersil maupun non-komersil. Namun peneliti menggunakan Perangkat lunak yang dibutuhkan dalam membangun media pembelajaran iniantara lain: Unity 3D, Vuforia SDK, Java JDK, Corel Draw X7, Adobe Photoshop CC2015, Format Factory, Star UML.

b. Tahap Perencanaan Arsitektur Sistem

Pada tahap ini, dilakukan perancangan arsitektur sistem yang akan dibangun. Rancangan sistem digambarkan dalam use case diagram, activity diagram, dan sequence diagram.

c. Tahap Perancangan Komponen Sistem

Komponen dalam aplikasi media pembelajaran dirancang dalam tahap ini. Perancangan mengacu pada analisis kebutuhan, analisis perangkat lunak, analisis perangkat keras, dan perencanaan arsitektur sistem. Rancangan aplikasi dibuat dalam sebuah storyboard. Storyboard merupakan gambaran secara visual tampilan media pembelajaran dalam bentuk sketsa.

d. Tahap Pembuatan Disain Antar Muka

Antar muka dibuat berdasarkan perancangan disain antar muka. Antar muka dibangun berdasarkan storyboard yang telah dibuat pada tahan perancangan disain antarmuka. Pada tahap ini software disain grafis digunakan dalam pembuatan disain antar muka. Software yang digunakan adalah Corel DrawX7 dari Corel Corporation dipadukan dengan Adobe Photoshop CC2015 dari Adobe. CorelDraw digunakan untuk membuat disain tampilan pada media yang meliputi background, tombol, soal, halaman kompetensi dasar, halaman Augmented Reality, halaman materi, halaman evaluasi, dan halaman profil. Adobe Photoshop digunakan untuk membuat icon lalu mengkonversi menjadi format portable network graphic (png). Berikut disain komponen antar muka yang ada dalam media pembelajaran.

1. Icon 
Icon menunjukkan gambar kecil untuk mewakili aplikasi media pembelajaran dalam menu utama. Icon biasa terdapat pada menu utama smartphone.

2. Splash Screen

Splash screen merupakan halaman muka yang pertama kali muncul. Halaman ini muncul ketika aplikasi dijalankan untuk menandakan aplikasi mulai bekerja.

3. Halaman Menu Utama

Merupakan halaman menu utama dalam media pembelajaran yang dapat diakses oleh pengguna. Menu yang terdapat dalam halaman ini adalah kompetensi dasar, augmented reality, materi, dan evaluasi. Menu kompetensi dasar untuk menunjukan kompetensi yang harus dicapai setelah mempergunakan media pembelajaran ini. Menu Augmented Reality, menu yang merupakan hasil penggabungan dari benda maya dengan benda nyata dalam satu waktu yang bersamaan. Menu materi, untuk mendukung menu Augmented Reality agar peserta didik lebih mudah memahami materi yang disajikan. Menu evaluasi, sebagai evaluasi mandiri yang dilakukan oleh peserta didik, untuk mengetahui sejauh mana keterserapan materi yang disampaikan melalui media yang digunakan. (Mustaqim, Ilmawan \& Kurniawan, 2017)

a) Menu Kompetensi Dasar

Menu ini terdapat isi kompetensi-kompetensi dasar yang terdapat di dalam materi pembelajaran PAI. Kompetensi dasar merupakan kemampuan minimal pada tiap mata pelajaran yang harus dicapai peserta didik. Kompetensi dasar dalam silabus berfungsi untuk mengarahkan guru mengenai target yang harus dicapai dalam pembelajaran. Misalnya, mampu menyelesaikan diri dengan lingkungan dan sebagainya. Pada penelitian ini kompetensi dasar yang digunakan adalah tentang sholat, bagaimana peserta didik bisa memahami tata cara sholat yang benar dan bisa menerapkan gerakan-gerakan sholat yang sesuai dengan al-quran dan hadis.

b) Menu Augmented Reality

Halaman ini terdapat kumpulan Augmented Reality yang sudah disiapkan sebelumnya oleh peneliti, karena disini peneliti mengumpulkan AR tentang gerakan sholat yang benar yang mana juga termasuk kedalam materi pembelajan PAI maka contoh gambar AR yang kami tampilkan adalah tentang gerakan sholat. Sebenarnya banyak lagi materi yang bisa disandingkan dengan media AR ini terutama terkait dengan pembelajaran PAI, seperti tata cara bersuci, berhaji, atau tata cara menulis bahasa arab dengan benar dan lain-lain yang mana disitu terdapat gerakan yang mendukung Augmented Reality. 


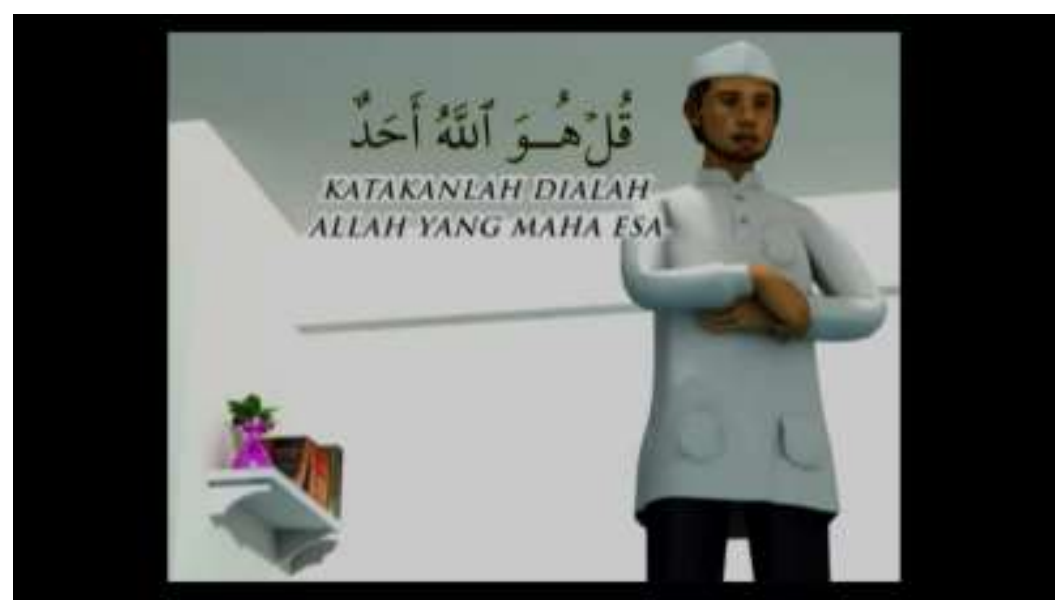

Gambar 2. Tampilan AR Pada Gerakan Sholat

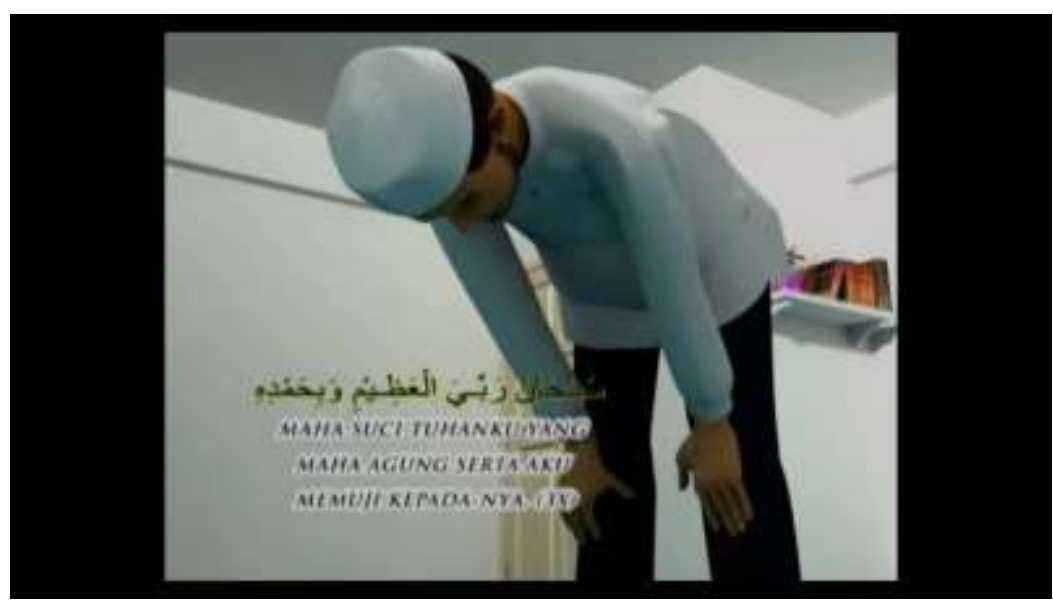

Gambar 3. Tampilan AR Pada Waktu Ruku'

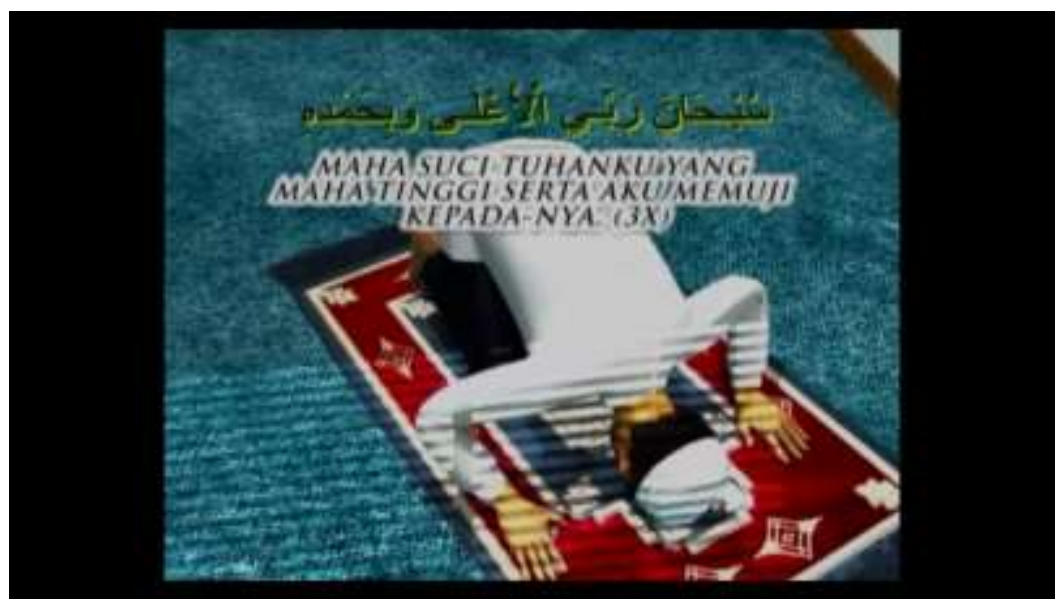

Gambar 4. Tampilan AR Pada Waktu Sujud 
c) Menu Materi

Menu materi ini berfungsi untuk menyimpan materi-materi pembelajaran terutama dalam yang terkait dengan pendidikan agama islam (PAI). Sebagai contoh kami menggunakan materi sholat yang mana dalam sholat ada geraraka-gerakan yang harus diketahui lebih detail oleh peserta didik, dan gerakan dalam sholat ini bisa dimasukkan ke dalam bentuk AR. Dengan memanfaatkan teknologi $A R$ ini maka diharapkan bagi yang baru belajar gerakan dan bacaan shalat akan semakin antusias dan tertarik dengan tuntunan shalat yang sudah dilengkapi dengan teknologi Augmented Reality dan yang jauh lebih penting adalah pengguna bisa melihat gambaran nyata dari gerakan-gerakan shalat yang menyerupai aslinya. Tidak hanya pada materi tentang gerakan sholat saja tapi ini juga bisa digunakan Materi yang lain seperti tuntunan manasik haji, cara menyembelih hewan dan lain-lain yang terkait dengan pembelajaran. pembelajaran disini adalah materi yang akan diajarkan oleh pendidik dan harus dapat dimengerti dan diterima oleh peserta didik.

d) Menu Evaluasi

Halaman ini berfungsi untuk memperbaiki materi pembelajaran yang belum dicapai atau belum mencapai tujuan pembelajan yang terkait dengan pembelajan Pendidikan Agama Islam. Jika peserta didik kurang memahami materi sebelumnya atau nilainya tidak sesuai dengan yang diharapkan maka di menu evaluasi ini peserta didik akan diperdalam lagi pemahaman mereka terutama pada materi-materi yang tidak mereka pahami dan juga ada ujian atau tes untuk mengukur evaluasi yang sudah dilakukan apakah itu sudah mencapai nilai yang diharapkan, jika masih belum maka aka ada evaluasi lanjutan.

e) Halaman Profil

Halaman ini menunjukkan biodata singkat pengembang media pembelajaran. Jadi halaman ini terdapat nama pengembang, alamat, tanggal lahir, pendidikan pengembang, serta pengalaman yang dialami olah pengembang selama dalam pembuatan aplikasi AR ini. Halaman ini dapat pula berisi cara penggunaan aplikasi AR yang mana masih belum dimengerti atau dipahami sebelumnya oleh guru atau peserta didik dan keterangan tambahan terkait dalam penggunaan AR ini.

e. Tahap Pembuatan Program

Proses pembuatan program adalah penyatuan dari tahap pembuatan disain antarmuka dengan berbagai aplikasi dalam bahasa pemrograman. Hasil akhir dari tahap ini adalah sistem yang mempunyai fungsionalitas sesuai dengan yang diharapkan. Langkah yang perlu dilakukan pada tahap ini adalah : (1) persiapan asset, yaitu memasang Unity 3D sebagai software utama pada komputer, (2) pembuatan marker, sebagai penanda obyek maya akan dipasang, (3) mengunggah 
marker yang dibuat ke Vuforia untuk dilakukan verifikasi (4) membuat proyek baru di Unity 3D (Mustaqim, Ilmawan \& Kurniawan, 2017).

Dimulai dari pembuatan menu utama dengan meng-import disain yang telah dibuatke proyek Unity 3D. Action diberikan ke setiap tombol untuk dapat bekerja ketika tombol ditekan. Pemrograman terus dilakukan hingga seluruh disain dapat dijalankan pada perangkat smartphone.

\section{SIMPULAN}

Dari uraian di atas, dapat ditarik beberapa kesimpulan. Media pembelajaran menjadi hal yang tidak terpisahkan dalam sebuah pembelajaran. Hal ini dikarenakan keberhasilan materi yang disampikan oleh guru turut dipengaruhi oleh media pembelajaran yang digunakan. Di era modern ini, media pembelajaran tentu sangat mudah didapatkan. Disamping mudah untuk mendapatkan, perlunya kejelian dalam memilih media yang digunakan. Media harus dapat menjangkau seluruh peserta didik dan menjadi solusi alternatif terhadap kurangnya semangat belajar peserta didik. Salah satu media yang tepat yaitu dengan menggunakan media berbasis Augmented Reality (AR)

Melaui Augmented Reality, guru dapat membuat media pembelajaran yang menyenangkan, interaktif, dan mudah digunakan. Augmented Reality juga dapat menggantikan modul pembelajaran yang belum ada di sekolah dalam bentuk virtual atau maya. Peserta didik tetap dapat melihat dan menggunakan modul seperti modul aslinya, namun dalam bentuk virtual. Melaui terobosan baru ini, semakin banyak variasi media pembelajaran yang dapat dibangun untuk mendukung kegiatan pembelajaran di sekolah, terutama dalam pembelajaran PAI.

\section{DAFTAR PUSTAKA}

Aditya. (2009). Trik Dahsyat Menjadi Animator 3D Handal. Yogyakarta: Andi.

Ardhianto, E. (2012). Augmented Reality Objek 3 Dimensi dengan Perangkat Artoolkit dan Blender. Dinamik-Jurnal Teknologi, 17(2), 107-117.

Arsyad, A. (2009). Media Pembelajaran. Jakarta: Radja Grafindo Persada.

Asyhar, R. (2012). Kreatif Mengembangkan Media Pembelajaran. Jakarta: Referensi Jakarta.

Baharun, H. (2016). Pengembangan Media Pembelajaran PAI Berbasis Lingkungan Melalui Model Assure.

Dengeng, I. N. S. (2001). Media Pembelajaran menuju Pribadi Unggul. Malang: LP3 Universitas Negeri Malang.

Dick, W. \& C. J. O. (2015). The Systematic Design of Instruction. New York: Pearsons.

Djamarah. (2006). Strategi Belajar Mengajar. Banjarmasin: Rineka Cipta.

Jogiyanto. (1990). Analisis dan Desain Sistem Informasi. Yogyakarta: Andi Ofset.

Legya, E. (2015). Pengembangan dan Analisis Media pembelajaran Perakitan Komputer Berbasis Augmented Reality untuk Platform Android di SMK YPKK 1 Sleman.

Mudjiono, D. (2013). Belajar dan Pembelajaran. Jakarta: Rineka Cipta. 
Muhaimin. (2004). Paradigma Pendidikan Islam, Upaya Mengefektifkan Pendidikan Agama Islam di Sekolah. Bandung: Remaja Rosdakarya.

Mustaqim, I., \& Kurniawan, N. (2017). Pengembangan Media Pembelajaran Berbasis Augmented Reality. Edukasi, 1.

Riyana., R. S. \& C. (2009). Media Pembelajaraan, Hakikat, Pengembangan, Pemanfaatan, dan Penilaian. Bandung: Wahana Pri.

Ronald, T. A. (1997). A Survey ofAugmented Reality. Teleoperatorsand Virtual Environments.

Sugiyono. (2013). Metode Penelitian Kualitatif Kuantitatif dan RED. Bandung: Alfabeta.

Suparman, A. (2012). Desain Instruksional Modern. Jakarta: Erlangga. 